Environment Conservation Journal 15(1 \& 2)95-98, 2014

ISSN 0972-3099 (Print) 2278-5124 (Online)

Abstracted and Indexed

\title{
Evaluation of physico-chemical and microbiological parameters of Jhajjar rivulet of $\mathbf{J} \& \mathrm{~K}$
}

\author{
Indu Bhushan Sharma $\bowtie$, Arvind Kumar Yadav and Vijeshwar Verma \\ Received: 18.09.2013 \\ Revised :22.01.2014 \\ Accepted:19.02.2014
}

\begin{abstract}
Water quality is an index of health and well being of a society. The pollution of water bodies is one of the areas of major concern to environment. In the present investigation an attempt has been made to evaluate the physical, chemical and microbiological parameters of Jhajjar rivulet of J\&K. The study has been carried out by taking water samples at three different sites of the rivulet i.e. site 1 , site 2 and site3. During the study, the physico-chemical parameters like pH, temperature, colour, total hardness, BOD, COD, DO, TDS and TSS in the water samples were studied. In microbiological examination, the presence of coliform in the water samples were studied. It has been observed that there was a pollution load mostly at site 3 and slightly at site 2 , it may be due to the release of huge quantities of sewage, effluent and manmade activities at the respective sites but the water from all the sites was found free from microbial contamination. It was concluded that water at site 1 is suitable for drinking as compared to site 2 and site 3 of the rivulet.
\end{abstract}

Keywords: Dissolved oxygen, Jhajjar rivulet, total suspended solids, total dissolved solids, water quality

\section{Introduction}

Water is a key component in determining the quality of our lives. Today, people are concerned about the quality of the water they drink. Although water covers more than $70 \%$ of the Earth, only $1 \%$ of the Earth's water is available as a source of drinking. Yet, our society continues to contaminate this precious resource. Before it reaches the consumer's tap, it comes into contact with many different substances, including organic and inorganic matter, chemicals, and other contaminants. Most illnesses that arise from contact with sewage are caused by pathogens, which are biological agents that cause disease or illness in a host. The most common pathogens in sewage are bacteria, parasites, and viruses. They cause a wide variety of acute illnesses including diarrhea and infections. In some cases, however, pathogens can cause serious long-term illnesses or even death. Keeping in view the tremendous importance of water for human health, we are trying to study the physical, chemical and microbiological parameters of the water of Jhajjar rivulet (Jammu \& Kashmir). Jhajjar also spelled as Jhajjar Kotli is situated about $35 \mathrm{~km}$ away from Jammu on the national highway leading towards Srinagar in Kashmir. The discharge Author's Address

Shri Mata Vaishno Devi University, Katra

E- mail: arvind.kuyad@gmail.com of huge quantities of sewage, effluents and more of the man made activities etc., have been major concern in water pollution. These effluents without proper treatment are discharged into the nearby aquatic bodies in large quantities causing massive destruction of aquatic flora and fauna by means of suspended solids, immediate depletion of oxygen content, undesirable taste and odour creating substances and by interfering the respiratory metabolism of the animals and aquatic lives. The small tourist site was constructed on the bank of Jhajjar rivulet that cascades through the valleys of this enchanting state of Jammu and Kashmir filled with clear and soothing water that often attracts a large crowd of tourists and local to its scenic picnic spots especially during summer season. The water of Jhajjar is used in many of the localareas like Sirah, Panthal, Manthal, Kakryal etc. The water is also supplied to Shri Mata Vaishno Devi University and Katra city. The Katra city is one of the biggest tourist place in Jammu and Kashmir due to Shri Mata Vaishno Devi. Jhajjar rivulet water is mainly used in these important areas for drinking, cooking, washing, bathing and for all the household purposes. Numerous aspects of river pollution such as physico-chemical properties of different river water (Mitra, 1982; Raina et al., 1984) and changes in biological composition of rivers with respect to 
impact of pollutants (Bhatt et al., 1985; Shukla, 1994) have been reported in India. Some investigation has also been conducted on physicochemical and biological aspects of river Godavari at different places (Deshmukh et al., 2006). As the quality of Godavari river water is getting deteriorated day by day and there is paucity of data on the pollution status. For physico-chemical analysis of water samples were collected from three different sites (Site 1 - Near Someshwar temple, Site 2 - Ramkund, Site 3 - Tapovan) (Fig. 1-3). Water samples were collected once in a month during the period Nov. 2002 - Oct. 2003. Samples were collected in cleaned plastic containers. Temperature and $\mathrm{pH}$ were measured in the field itself using digital thermometer and $\mathrm{pH}$ meter respectively. While remaining parameters were analyzed in the laboratory following the standard methods given by APHA (1998), Trivedy and Goel (1986). Similar observations were observed by Chakraborty and Asthana (1984), Mehta (1999) and Khanna and Bhutiani (2003).

\section{Material and Methods}

The collected samples were stored in cleaned, high density polyethylene (HDPE) bottles. The use of HDPE bottles minimizes container pollution and promotes the sample preservation (Hall, 1998)]. Samples were stored in refrigerator at $4^{0} \mathrm{C}$ prior to analysis. The physico-chemical parameters and biological parameters were analysed following the standard methods of APHA (1998), Trivedi and Goel (1986) and Khanna and Bhutiani (2004). The temperature was recorded at the different sites with the help of mercury thermometer, $\mathrm{pH}$ were measured in the field itself using $\mathrm{pH}$ metre and dissolved oxygen was analysed in the laboratory using Wrinkler's modified iodide-azide method. Chemical oxygen demand (COD) is measured by dichromate reflux method using a ferroin indicator. Hardness of sample is determined by complex metric titrations. The total coliforms test was performed using standard method of multiple tube fermentation tests. The test consists of three steps a presumtive test, confirm test and completed test. In the present study presumtive test was performed using five tube methods. The test tubes were incubated for 24 to 48 hours and then examined for the presence of coliforms which is indicated by gas and acid production.

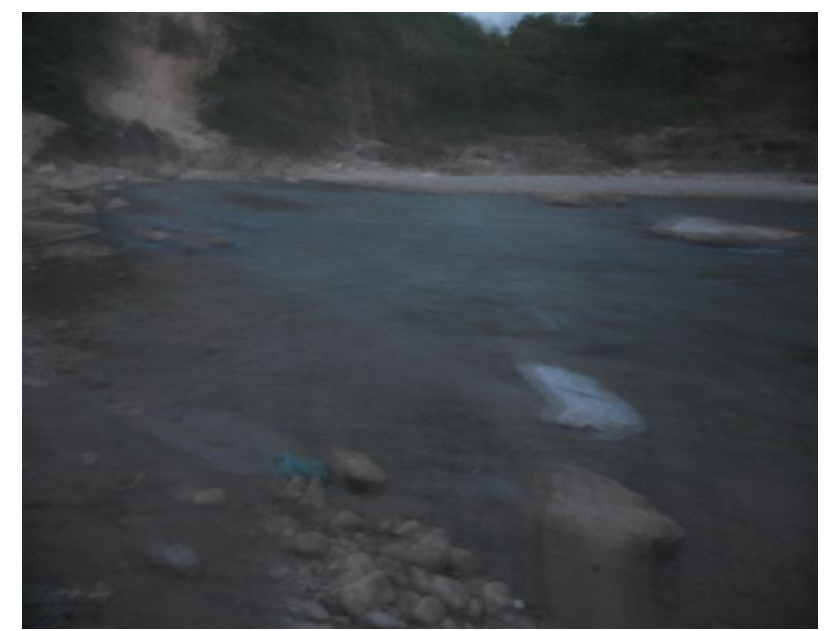

Fig 1. Sampling site1 showing upstream of Jhajjar

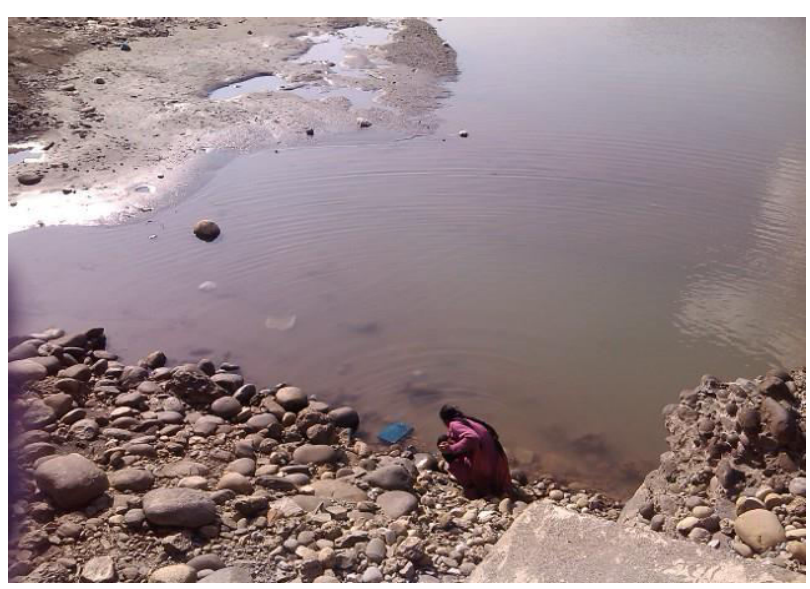

Fig.2. Showing sampling site 2 near the university campus

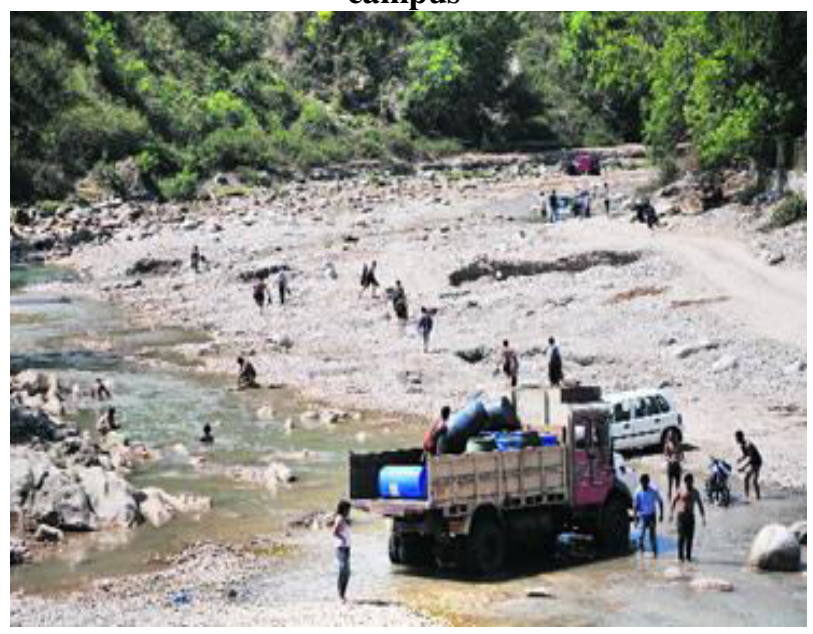

Fig.3: Showing sampling site 3 Downstream of Jhajjar after the Jhajjar Kotle park 


\section{Results and Discussion}

The Physico-chemical and biological studies of Jhajjar rivulet at three different sites has been shown in table 1 . In the present study it was observed that the colour of water samples collected from all the three sites such as Site 1, Site 2 and Site 3 was found transparent. The $\mathrm{pH}$ value of pure water is 7 while alkalinity or acidity has effect on it. The $\mathrm{pH}$ of sample at Site-1 and Site 2 was recorded as 7.2 while at Site-3 it has shown basicity i.e., 8.0.
Sharma et al., (2011), reported the water was alkaline throughout the study. It may be due to the addition of some waste discharges from the surrounding communities which is of alkaline in nature.The total suspended solid (TSS) is a measure of degree of quality of water and its presence is objectionable in river for many reasons. In this study the total suspended solids has been found $25 \mathrm{mg} / \mathrm{l}$ at Site $1,28 \mathrm{mg} / \mathrm{l}$ at site 2 and $32 \mathrm{mg} / \mathrm{l}$ at site 3 .

Table 1: Physico-chemical and microbiological parameters of water at different sites of Jhajjar rivulet

\begin{tabular}{|l|l|l|l|l|}
\hline S.No & Parameters & Site 1 & Site 2 & Site 3 \\
\hline 1 & $\mathrm{pH}$ & 7.2 & 7.2 & 7.5 \\
\hline 2 & Colour & Transparent & Transparent & Transparent \\
\hline 3 & Temperature $\left({ }^{0} \mathrm{C}\right)$ & 20 & 20 & 20 \\
\hline 4 & Total hardness Ppm & 119 & 125 & 125 \\
\hline 5 & B.O.D $(\mathrm{mg} / \mathrm{l})$ & 6 & 6 & 8 \\
\hline 6 & D.O(mg/l) & 9 & 9 & 7 \\
\hline 7 & C.O.D(mg/l) & 17 & 20 & 20 \\
\hline 8 & TDS $(\mathrm{mg} / \mathrm{l})$ & 20 & 26 & 26 \\
\hline 9 & TSS(mg/l) & 25 & 28 & 32 \\
\hline 10 & $\begin{array}{l}\text { MPN count of } \\
\text { coliforms/100ml sample }\end{array}$ & 6 & 11 & 11 \\
\hline
\end{tabular}

Whereas the total dissolved solid observed at site 1 are dangerous for aquatic life. Highest level of was $20 \mathrm{mg} / \mathrm{l}$ and at the other sites it was $26 \mathrm{mg} / \mathrm{l}$. BOD at sampling site- 3 indicates that it was most Hardness of water is mainly due to $\mathrm{Ca}^{++}$and $\mathrm{Mg}^{++}$ ions present in water. The hardness of water measured at Site 1 was $119 \mathrm{ppm}$ and $125 \mathrm{ppm}$ at Site 2 and Site 3. The higher concentration of chlorides, sulphates, nitrates, carbonates of $\mathrm{Ca}$ and $\mathrm{Mg}$, contributes to high salinity in water. BOD is measure of amount of oxygen consumed by microorganism during decomposition of organic matter in water sample. In Jhajjar rivulet BOD at site 1 and site 2 has been found $6 \mathrm{mg} / \mathrm{l}$ respectively whereas at site 3 it was $8 \mathrm{mg} / 1$, which indicates the presence of organic matter in water sample that causes depletion of dissolved oxygen in water and which polluted by organic effluent. COD determines the amount of oxygen required for chemical oxidation of organic matter using a strong chemical oxidant such as $\mathrm{K}_{2} \mathrm{CrO}_{4}$ under reflux condition. In Jhajjar rivulet maximum COD recorded was $20 \mathrm{mg} / \mathrm{l}$ at Site 2 and site 3 as it receives higher pollution load of residential andcommercial establishment in comparison to the site 1 where the COD recorded was $17 \mathrm{mg} / \mathrm{l}$. Dissolved oxygen (DO) value is a measure of degree of organic matter present in the water sample. The high DO value $(9.0 \mathrm{mg} / \mathrm{l})$ was found at sampling site 1 and site 2 whereas the lower DO value $(7 \mathrm{mg} / \mathrm{l})$ has been observed at site 
3 where high effluent discharge was found. The addition of wastes produced by the manmade activities affect the quality of water like DO, BOD, COD, TDS, TSS etc., was reported by Yadav and Bhushan (2012) and Khanna and Bhutiani (2003). Kulkarni et al., (2002) reported the similar study on Khushavati river. The multiple tube fermentation test allows for the detection and presence of coliforms in a water sample and estimation of the presence of their maximum probable number (MPN). In this investigation the MPN count found at Site-1, Site-2 and Site-3 was 6, 11 and 20 per 100 $\mathrm{ml}$ of sample respectively, which is within permissive limits.

\section{Conclusion}

In the present investigation, water samples collected from the different sites of Jhajjar rivulet is evident in all physico-chemical, and microbiological parameters examined. It was observed that the water samples studied at site 1 are within the range of standard values prescribed by various agencies whereas there is a pollution load mostly at site 3 and slightly at site 2 , it may be due to continuous dumping of municipal sewage, domestic waste, effluent, agricultural runoff and other man made activities in to the rivulet water. However the water samples studied from all the sites was found free from microbial contamination. It was concluded that water at site 1 is suitable for drinking purpose but the water at site 2 and site 3 is not satisfactory and is unsuitable for drinking purpose and other domestic uses. It is suggested that dumping of any type of the wastes without prior and proper treatment should be stopped.

\section{Acknowledgement}

Authors are very thankful to the higher authorities of Shri Mata Vaishno Devi University, Katra for providing the necessary facilities to carry out this investigation.

\section{References}

APHA, AWWA and WEF. 1998. Standards Methods for the examination of water and wastewater, $20^{\text {th }}$ edition, American Public, Health Association, American Water Work Association and Water Environmental Federation, Washington, DC 2005-2605.
Bhatt S.D, Yashodhara B and Negi U. 1985. Hydrology and phytoplankton populations in river Koshi of western Himalaya (U.P.), Ind.Jr.Eco. 12(1): 141-146.

Chakraborty, P. and Asthana, A. 1984. Planktonic succession and ecology of a sewage treated pond in W. Bengal. Environ and E. Co. 7 (3): 549 - 554.

Deshmukh, J.U. Ambore, N.E. and Pulle, J.S. 2006. BOD variations in Godavari river at Nanded city due to impact of industrial pollution. Ecol. Env. Cons.12(3): pp.533-534.

Hal,l Gem. 1998. Relative contamination levels observed in different typed of bottles used to collect water samples. Explore

Khanna, D.R. and Bhutiani, R. 2003. Limnological status of Satikund Pond at Haridwar (U.A.) Indian Journal of Environmental Sciences, 7(2): 131-136.

Khanna, D.R. and Bhutiani, R. 2004. Water analysis at a glance, ASEA publication, Rishikesh.

Kulkarni R.R., Sharma, R.N. and Burkari, M. 2002. Diurnal variations of physico-chemical aspects of pollution in Khushavati River at Quepem, Goa.. Aqua. Bioi., 17: 27-28.

Mehta, Vijay 1999. Eco-physiology and conservation of Kala Talav. Ph.D. Thesis., Uni. - Mumbai.

Mitra, A.K. 1982. Chemical characters of surface water at a selected gauging station in the river Godavari ,Krishna and Tungbhadra. Ind. J. Environ. Hlth., 24 (2): 165 - 179.

Raina V., Shah A.R. and Shakto A.R. 1984. Pollution studies on water quality. Indian J. Environ. Hlth. 26(3): 187-201.

Sharma, S. Vishwakarma, R. Dixit S and Jain, P. 2011. Evaluation of water quality of Narmada river with reference to Physico-chemical parameters at Hoshangabad city, M.P. India. Res. J. Chem. Sci. Vol. 1(3): 14.

Shukla Ramesh 1994. Pollution load through heavy metals and organo chlorines in the river Ganga, India INTELCOL, Manchester.

Trivedy, R.K. And Geol, P.K. 1986. Chemical and biological methods for water pollution studies, Environmental publications, Karad, India.

Yadav, A.K. and Bhushan, I. 2012. Physico-chemical studies of water quality in Banganga (Small River) of Shri Mata Vaishno Devi, Katra, J \& K, Environment Conservation Journal, 13(3): 61-63. 